\title{
RESEARCHPAPER
}

\section{Inter-characters associations in pearl millet (Pennisetum glaucum L.R.Br.) germplasm in hot-arid climate}

\author{
OM VIR SINGH AND A.K. SINGH \\ National Bureau of Plant Genetic Resources, Regional Station, CAZRI Campus, JODHPUR (RAJASTHAN) INDIA
}

Article Info :Received : 06.07.2015; Revised : 23.08.2015; Accepted : 09.09.2015

The forty six accessions of pearl millet germplasm collected from different places were studied during Kharif 2012 and 2013 in a Randomized Complete Block Design in the hot arid climate of Rajasthan. The study was conducted to assess the magnitude of presence of genetic variability and inter-characters associations of the characters namely, number of tillers per plant, plant height $(\mathrm{cm})$, panicle length $(\mathrm{cm})$, panicle diameter $(\mathrm{cm})$, number of leaves per plant, days to 50 per cent flowering and test weight $(\mathrm{cm})$. The result showed that genetic variability was present among the accessions for all studied characters. The estimated PCV (\%) and GCV (\%) were moderate to high for all characters. The broad sense heritability (\%) and genetic advance (\% of mean) estimates were moderate to high for all studied characters. The number of tillers per plant, plant height $(\mathrm{cm})$, panicle length $(\mathrm{cm})$, panicle diameter $(\mathrm{cm})$, number of leaves per plant, days to 50 per cent flowering and test weight $(\mathrm{cm})$ had positive and significant genotypic, phenotypic and environmental correlation co-efficients with grain yield per plant. The presence of genetic variability, high heritability and genetic advance and association with grain yield of all studied characters amenable them for selection and enhancement of grain yield.

Key words : Pearl millet, Germplasm, Correlation, Variability, Hot-arid

How to cite this paper : Singh, Om Vir and Singh, A.K. (2015). Inter-characters associations in pearl millet (Pennisetum glaucum L.R.Br.) germplasm in hot-arid climate. Asian J. Bio. Sci., 10 (2) : 143-147. 